\title{
Impact of co-existence of PMQR genes and QRDR mutations on fluoroquinolones resistance in Enterobacteriaceae strains isolated from community and hospital acquired UTIs
}

\author{
Dalia Nabil Kotb, Wafaa Khairy Mahdy, Mahmoud Shokry Mahmoud and Rasha M. M. Khairy * (D)
}

\begin{abstract}
Background: Fluoroquinolones are commonly recommended as treatment for urinary tract infections (UTIs). The development of resistance to these agents, particularly in gram-negative microorganisms complicates treatment of infections caused by these organisms. This study aimed to investigate antimicrobial resistance of different Enterobacteriaceae species isolated from hospital- acquired and community-acquired UTIs against fluoroquinolones and correlate its levels with the existing genetic mechanisms of resistance.

Methods: A total of 440 Enterobacteriaceae isolates recovered from UTIs were tested for antimicrobial susceptibility. Plasmid-mediated quinolone resistance (PMQR) genes and mutations in the quinolone resistance-determining regions (QRDRs) of gyrA and parC genes were examined in quinolone-resistant strains.

Results: About (32.5\%) of isolates were resistant to quinolones and (20.5\%) were resistant to fluoroquinolones. All isolates with high and intermediate resistance phenotypes harbored one or more PMQR genes. QnrB was the most frequent gene (62.9\%) of resistant isolates. Co-carriage of 2 PMQR genes was detected in isolates (46.9\%) with high resistance to ciprofloxacin (CIP) (MICs $>128 \mu \mathrm{g} / \mathrm{mL})$, while co-carriage of 3 PMQR genes was detected in (6.3\%) of resistant isolates (MICs $>512 \mu \mathrm{g} / \mathrm{mL}$ ). Carriage of one gene only was detected in intermediate resistance isolates (MICs of CIP $=1.5-2 \mu \mathrm{g} / \mathrm{mL}$ ). Neither gnrA nor gnrC genes were detected. The mutation at code 83 of gyrA was the most frequent followed by Ser80-lle in parC gene, while Asp-87 Asn mutation of gyrA gene was the least, where it was detected only in high resistant $E$. coli isolates (MIC $\geq 128 \mu \mathrm{g} / \mathrm{mL}$ ). A double mutation in gyrA (Lys $154 \mathrm{Arg}$ and Ser171Ala) was observed in high FQs resistant isolates (MIC of CIP $<128 \mu \mathrm{g} / \mathrm{mL}$ ).
\end{abstract}

Conclusion: FQs resistance is caused by interact between PMQR genes and mutations in both gyrA and parC genes while a mutation in one gene only can explain quinolone resistance. Accumulation of PMQR genes and QRDR mutations confers high resistance to FQs.

Keywords: Enterobacteriaceae, Fluoroquinolones, Plasmid-mediated quinolone resistance, Quinolone resistancedetermining regions (QRDRs)

\footnotetext{
* Correspondence: rashakhiry1@gmail.com

Department of Microbiology and Immunology, Faculty of Medicine, Minia

University, Minia 61511, Egypt
}

(c) The Author(s). 2019 Open Access This article is distributed under the terms of the Creative Commons Attribution 4.0 International License (http://creativecommons.org/licenses/by/4.0/), which permits unrestricted use, distribution, and reproduction in any medium, provided you give appropriate credit to the original author(s) and the source, provide a link to the Creative Commons license, and indicate if changes were made. The Creative Commons Public Domain Dedication waiver (http://creativecommons.org/publicdomain/zero/1.0/) applies to the data made available in this article, unless otherwise stated. 


\section{Background}

Urinary tract infections (UTIs) are common infectious diseases in both hospital- acquired UTI (HAUTI) and community-acquired UTI (CA-UTI) [1, 2]. UTI can be diagnosed by at least one of the following clinical symptoms or signs; temperature $\geq 38^{\circ} \mathrm{C}$, suprapubic pain, costovertebral angle pain, urinary urgency, dysuria or frequency. A quantitative urine culture with bacterial counts $\geq 10^{5}$ colony forming units per $\mathrm{mL}(\mathrm{CFU} / \mathrm{mL})$ is essential for the diagnosis of UTI [3]. UTIs may be caused by gram-negative, gram-positive bacteria or by fungi. E. coli is the most common cause followed by Klebsiella and other Enterobacteriaceae in both CA-UTI [4] and hospital- acquired UTI (HAUTI) [5]. Fluoroquinolones (FQs) have been considered a highly effective treatment of UTIs. However, the development of resistance to these agents especially by gram-negative microorganisms complicates the treatment of infections caused by these organisms [6]. FQs resistance is mainly caused by spontaneous mutations in the quinolone resistance determining regions (QRDR) of gyr A and par C genes, either gyr A or par C, or both genes [7]. However, in the past few decades, plasmid-mediated quinolone resistance (PMQR) has been increasingly reported in $E n-$ terobacteriaceae species all over the world [8]. The coexistence of mutations in QRDR and PMQR genes carriage can occur together in Enterobacteriaceae species. Moreover, the presence of PMQR determinants may promote QRDR mutations increasing the FQs resistance rates [9]. Some studies in Egypt have previously investigated the FQs resistance $[10,11]$, but the study of contribution of various mechanisms of resistance in different Enterobacteriaceae species in immunocompetent patients was not addressed. Accordingly, the aim of the current study was to investigate antimicrobial resistance of different Enterobacteriaceae species isolated from CAUTI and HAUTI against FQs and correlate its levels with the existing genetic mechanisms of quinolones $(\mathrm{Qs})$ resistance.

\section{Methods}

\section{Study design}

This is a cross-sectional study was conducted in Minia university hospitals, Egypt, from July 2016 to March 2017. A total of 705 patients with suggested UTI (presented with one or more of UTI symptoms; (Fever $\geq 38^{\circ} \mathrm{C}$, dysuria, increased frequency and suprapubic pain) were included in the study. Urine samples with positive pyuria and urine cultures with a colony count for a single bacterial species $\geq 10^{5} \mathrm{CFU} / \mathrm{mL}$ were only included. The study populations were adults ( $>18$ years). About $32.2 \%$ of participants were males and $67.8 \%$ were females. The study included 418 outpatients (attended at outpatient's clinics seeking the treatment) and 286 inpatients (developed their clinical symptoms after $48 \mathrm{~h}$ of admission). This study was carried out according to the principles of the declaration of Helsinki. The study was approved by the Medical Ethics Committee of Minia university Hospital, Egypt. As the study used anonymous clinical data, the patients were not required to give informed consent for the study (code: $45 \mathrm{~A}$ at 2/5/2016).

\section{Bacterial strains}

Urine specimens were collected from symptomatic patients in sterile screw capped containers that were transported within $2 \mathrm{~h}$ of collection to bacteriology laboratory in an ice box and processed at once. Well-mixed uncentrifuged urine specimens were streaked by semi-quantitative streaking method onto UTI chrome agar (CHROMagar ${ }^{\text {ma }}$ Orientation, paris, France) and by calibrated loop technique on MacConkey and blood agars [12]. After overnight incubation at $37^{\circ} \mathrm{C}$, isolated uropathogens were further identified according to their phenotypic criteria based on gram staining, cultural characters and biochemical testing including indole, urease, citrate and sugar fermentation tests [12]. Confirmed Enterobacterecieae strains were kept in trypticase soy broth with sterilized $15 \%$ glycerol at $-20^{\circ} \mathrm{C}$. A total of 440 non-repetitive Enterobacterecieae isolates were recovered from urine samples.

\section{Antimicrobial susceptibility testing}

According to CLSI guidelines [13], disk diffusion method was used to determine antimicrobial susceptibility of the Enterobacteriaceae isolates to different antibiotics; amoxicillin/clavulanic acid (AMC) $30 \mu \mathrm{g}$, ceftriaxone (CRO) $30 \mu \mathrm{g}$, ceftazidime (CAZ) $30 \mu \mathrm{g}$, imipenem (IPM) $10 \mu \mathrm{g}$, amikacin (AK) $30 \mu \mathrm{g}$, sulphamethoxazole/ trimethoprim (SXT) $25 \mu \mathrm{g}$, and nitrofurantoin (F) $300 \mu \mathrm{g}$. Also 4 different antibiotics discs for quinolone $(\mathrm{Q})$ and fluoroquinolones $(\mathrm{FQs})$ resistance were used; nalidixic acid (NA) $30 \mu \mathrm{g}$, ciprofloxacin (CIP) $5 \mu \mathrm{g}$, norfloxacin (NOR) $10 \mu \mathrm{g}$ and ofloxacin (OFX) $5 \mu \mathrm{g}$ (Thermo Scientific $^{\text {Tix }}$ Oxoid, UK). Minimum inhibitory concentration (MIC) of ciprofloxacin (CIP) was determined by two methods; MIC strips (E test) which graded from 0.002 to $32 \mu \mathrm{g} / \mathrm{mL}$ and agar dilution method. MIC strips (E test) (Liofilchem s.r.l, Italy) were placed on surfaces of inoculated Mueller-Hinton agar plates as explained previously [12]. MIC determination by agar dilution method was performed according to CLSI guidelines (CLSI, 2015 and CLSI*, 2015), where ten concentrations $(4-2048 \mu \mathrm{g} / \mathrm{mL})$ of CIP were prepared (each in a single agar plate) [14, 15]. The results of disk diffusion assay as well as MIC were interpreted according to CLSI guidelines [13].

\section{DNA extraction and PCR amplification}

DNA was extracted using GeneJET genomic DNA purification kit (Thermosceintific, USA) according to the 
manufacturer's instructions. PMQR genes; qnrA, qnrB and $q n r S$ were tested by a multiplex PCR reaction using specific primers (Table 1). PCR was performed in a $25 \mu \mathrm{L}$ reaction mixture containing $5 \mu \mathrm{L}$ of purified DNA (approximately $500 \mathrm{ng} /$ 휄 $\mathrm{L}$ ), $12.5 \mu \mathrm{L}$ of Platinum ${ }^{\circ}$ multiplex PCR master Mix (Applied Biosystems $\mathrm{s}^{\mathrm{Tw}}$, USA), 0.8 휠 $\mathrm{L}(8 \mathrm{pmol})$ of each primer and $2.7 \mu \mathrm{L}$ of nuclease free water. Single PCR reactions were used for amplification of each of PMQR genes ( $q n r C$ and $q e p A$ ) and QRDRs of gyrA and parC genes using specific primers (Table 1). Each single PCR reaction was performed in a $25 \mu \mathrm{L}$ reaction mixture containing $300 \mathrm{ng} /$ 휄 $\mathrm{L}$ of DNA, $12.5 \mu \mathrm{L}$ of AmpliTaq Gold $^{\circ} 360$ master mix (Applied Biosystems ${ }^{\text {ra }}$, USA), $1 \mu \mathrm{L}(10 \mathrm{pmol})$ of each primer and $7.5 \mu \mathrm{L}$ of nuclease free water. The primers sequences, annealing temperature, and size of amplified fragments for the studied genes are shown in Table 1 [16-20]. PCR products were resolved on $1 \%$ agarose gel with ethidium bromide dye and the gel was visualized under a UV transilluminator (Biometra Goettingen, Germany).

\section{Sequencing of PCR products}

Sequencing was carried out using an automated DNA sequencer and data collection software from Applied Biosystems, USA. Translated nucleotide sequences of QRDR in gyrA and parC genes were compared with corresponding reference protein sequences using BLAST software of NCBI; National Center for Biotechnology Information (http://www.ncbi.nlm.nih.gov/blast). GyrA accession number used for E. coli was WP_074153749.1, for Klebsiella spp. was WP_075874334.1 and for Citrobacter spp. was WP_044266198.1. Accession number for parC was AML00471.1.

\section{Statistical analysis}

Statistical analysis of demographic, clinical and laboratory data of study subjects was performed using SPSS for windows version 19.0 (IBM, USA).

\section{Results}

Prevalence of Enterobacteriaceae strains among UTIs

Four hundred and forty isolates belonging to Enterobacteriaceae family were recovered from UTI patients with a percentage of $(440 / 705,62.4 \%)$. Two hundred and nine $(209 / 286,73.1 \%)$ were from inpatients and $(231 / 418$, $55.1 \%)$ were from outpatients. E. coli was the most frequent pathogen (281/440 (63.9\%), followed by Klebsiella pneumoniae (K. pneumoniae) $(81 / 440,18.4 \%)$, Citrobacter spp. (47/440, 10.7\%), Proteus spp. (20/440, 4.5\%) and lastly Enterobacter spp. (11/440, 2.5\%), (Table 2).

\section{Antimicrobial susceptibility profiles of Enterobacteriaceae isolates}

Of 440 Enterobactericeae clinical isolates tested for antimicrobial susceptibility, the highest rates of resistance were observed against SXT (253/440, 57.5\%), CRO (217/ $440,49.3 \%)$ and AMC (159/440, 36.1\%). while the highest susceptibility rate was found to IMP (440/440, $100 \%)$. Percentages of resistant isolates to tested antimicrobial agents are summarized in Table 3.

\section{Quinolone (Q) and fluoroquinolones (FQs) susceptibility}

A total of $(143 / 440,32.5 \%)$ Enterobacteriaceae isolates were resistant to one or more of the tested (Q and FQs). Out of them $(90 / 440,20.5 \%)$ were resistant to FQs. These isolates could be categorized into three phenotypes; high resistance phenotype which included 67 isolates that were highly resistant to all tested $\mathrm{Q}$ and FQs

Table 1 PCR primers used in the current study

\begin{tabular}{|c|c|c|c|c|}
\hline Primer name & Primer sequence $\left(5^{\prime}\right.$ to $\left.3^{\prime}\right)$ & PCR product size (bp) & Annealing Temperature & Ref \\
\hline qnrA m-F & AGAGGATTTCTCACGCCAGG & 580 & $54^{\circ} \mathrm{C}$ & [16] \\
\hline qnrA $\mathrm{m}-\mathrm{R}$ & TGCCAGGCACAGATCTTGAC & & & \\
\hline qnrB m-F & GGMATHGAAATTCGCCACTG & 264 & $54^{\circ} \mathrm{C}$ & [16] \\
\hline qnrB m-R & TITGCYGYYCGCCAGTCGAA & & & \\
\hline qnrs m-F & GCAAGTTCATTGAACAGGGT & 428 & $54^{\circ} \mathrm{C}$ & [16] \\
\hline qnrs m-R & TCTAAACCGTCGAGTTCGGCG & & & \\
\hline $\operatorname{anrC-F}$ & GGGTTGTACATTTATTGAATC & 447 & $50^{\circ} \mathrm{C}$ & [17] \\
\hline $\operatorname{anrC-R}$ & TCCACTITACGAGGTTCT & & & \\
\hline qepA-GF & ACATCTACGGCTTCTTCGTCG & 502 & $55^{\circ} \mathrm{C}$ & [18] \\
\hline qepA-GR & AACTGCTTGAGCCCGTAGATC & & & \\
\hline $\operatorname{parc}-\mathrm{F}$ & ATG TAC GTG ATC ATG GAC CG & 300 & $55^{\circ} \mathrm{C}$ & [19] \\
\hline parc-R & ATT CGG TGT AAC GCA TCG CC & & & \\
\hline gyrA-F & AAA TCT GCC CGT GTC GTT GGT & 343 & $55^{\circ} \mathrm{C}$ & [20] \\
\hline gyrA-R & GCC ATA CCT ACG GCG ATA CC & & & \\
\hline
\end{tabular}


Table 2 prevalence of different species of Enterobacteriaceae isolated from UTIs

\begin{tabular}{|c|c|c|c|c|c|c|c|}
\hline \multirow[t]{3}{*}{ Organism } & \multicolumn{6}{|c|}{ Frequency } & \multirow[t]{3}{*}{$P$ value } \\
\hline & \multicolumn{2}{|c|}{ Total } & \multicolumn{2}{|c|}{ Outpatients } & \multicolumn{2}{|c|}{ Inpatients } & \\
\hline & $\bar{N}$ & $\%$ & $\mathrm{~N}$ & $\%$ & $\bar{N}$ & $\%$ & \\
\hline E.coli & 281 & $63.9 \%$ & 147 & $63.6 \%$ & 134 & $64.1 \%$ & 0.0001 \\
\hline K. pneumoniae & 81 & $18.4 \%$ & 40 & $17.3 \%$ & 41 & $19.6 \%$ & \\
\hline Citrobacter spp. & 47 & $10.7 \%$ & 17 & $7.4 \%$ & 30 & $14.4 \%$ & \\
\hline Enterobacter spp. & 11 & $2.5 \%$ & 9 & $3.9 \%$ & 2 & $1.0 \%$ & \\
\hline Proteus spp. & 20 & $4.5 \%$ & 18 & $7.8 \%$ & 2 & $1.0 \%$ & \\
\hline Total & 440 & $100 \%$ & 231 & $100 \%$ & 209 & $100 \%$ & \\
\hline
\end{tabular}

UT/s Urinary tract infections

with MIC of CIP $>32 \mu \mathrm{g} / \mathrm{mL}$, intermediate resistance phenotype which included 23 isolates with intermediate resistance to all tested Q and FQ with MIC of CIP $=1-$ $2 \mu \mathrm{g} / \mathrm{mL}$. FQs susceptible phenotype which included 53 isolates that were resistant to NA only (Q) and susceptible to all tested FQs with MIC of CIP $\leq 1 \mu \mathrm{g} / \mathrm{mL}$.

\section{Prevalence of PMQRs}

Of the $143 \mathrm{Q}$ resistant isolates, 90 isolates (62.9\%) harbored at least one PMQR gene (54 E. coli, 17 Citrobacter, $9 \mathrm{~K}$. pneumoniae and 10 Proteus). The most frequent PMQR gene was $q n r B$, which was detected in $(90 / 143$, $62.9 \%)$ of $\mathrm{Q}$ and FQs resistant isolates and in (90/90, $100 \%)$ of FQs resistant isolates. QnrS gene was detected in $(67 / 143,46.9 \%)$ of $Q$ and FQs resistant isolates and in (67/90, 74.4\%) of FQs resistant isolates (Additional file 1: Figure S1). Neither $q n r A$ nor $q n r C$ were detected in the studied isolates. qepA gene was detected in (9/143, 6.3\%) of $\mathrm{Q}$ and FQs resistant isolates and in (9/90, 10\%) of FQs resistant isolates. (Additional file 2: Figure S2) (Table 4).

\section{QRDR mutations in gyrA and parC genes}

$\mathrm{Q}$ and FQs resistant isolates were studied by PCR and subsequent sequencing of QRDR of their gyrA and parC genes. Mutation at codon 83 of gyrA was detected in $(102 / 143,71.3 \%)$ of $\mathrm{Q}$ resistant isolates; 51 of them belong to high resistance phenotype, 20 in intermediate phenotype and 31 belong to the FQs susceptible phenotype (resistant to NA only) (Figs. 1 and 2). Mutation at codon 87 (Asp87Asn) of gyrA was detected in high resistance phenotype only (6 isolates) (Fig. 3). Three types of amino acid changes resulted from mutation at codon 83 of gyrA protein; change from serine to leucine in $E$. coli, from serine to tyrosine which was detected in $E$. coli and Klebsiella and from serine to isoleucine in Citrobacter strains. Mutation at position 80 of parC gene was detected in $(78 / 143,54.5 \%)$ of isolates (Fig. 4); 57 of them belong to high resistance phenotype, 2 isolates (intermediate resistance) and 19 isolates (FQs susceptible phenotype). Isolates' identification, phenotypes, PMQR genes distribution and detected mutations are summarized in (Table 4).

\section{Correlation between phenotyping and genotyping of resistant isolates}

All isolates with high resistance phenotype (67) harbor QnrB and qnrS genes. QepA gene was detected in only 9 isolates with high resistance phenotype. Isolates with intermediate resistance phenotype (23) carry qnrB gene only. None of PMQR genes was found in isolates with FQs susceptible isolates (resistant to NA only). Detection of PMQR genes ( $q n r B$ and $q n r S$ ) was strongly correlated with FQs resistance levels in resistant isolates with a correlation coefficient equal to $0.8(\mathrm{r}=0.8)$ and $0.9(\mathrm{r}=0.8)$ respectively which was highly significant ( $p$ value; 0.0001 ) for both genes as well as qepA gene with a correlation coefficient equal to $0.25(\mathrm{r}=0.25)$ which was considered fair but significant ( $p$ value; 0.006$)$. Detection of specific mutations in gyrA and parC genes was not correlated with susceptibility pattern to tested Q and FQs as these mutations were found in all phenotypes (Table 4).

\section{Discussion}

UTIs are common bacterial infections in hospital settings and community [21]. In the current study, 440 Enterobacteriaceae isolates were isolated from UTIs with a percentage of $(440 / 705,62.4 \%)$. The isolation rates from inpatients and

Table 3 Patterns of antimicrobial resistance of Enterobacteriaceae species isolated from UTIs

\begin{tabular}{|c|c|c|c|c|c|c|c|c|c|c|c|c|c|c|c|c|c|c|c|c|c|c|}
\hline \multirow{2}{*}{$\begin{array}{l}\text { Antibiotic } \\
\text { organism }\end{array}$} & \multicolumn{2}{|c|}{$\mathrm{AMC}$} & \multicolumn{2}{|l|}{ CTZ } & \multicolumn{2}{|l|}{$\mathrm{CRO}$} & \multicolumn{2}{|c|}{ IMP } & \multicolumn{2}{|l|}{ AK } & \multicolumn{2}{|l|}{ SXT } & \multicolumn{2}{|l|}{ NA } & \multicolumn{2}{|l|}{ CIP } & \multicolumn{2}{|c|}{ NOR } & \multicolumn{2}{|c|}{ OFX } & \multicolumn{2}{|l|}{$\mathrm{F}$} \\
\hline & $\mathrm{N}$ & $\%$ & $\mathrm{~N}$ & $\%$ & $\mathrm{~N}$ & $\%$ & $\mathrm{~N}$ & $\%$ & $\mathrm{~N}$ & $\%$ & N & $\%$ & $\mathrm{~N}$ & $\%$ & $\mathrm{~N}$ & $\%$ & $\mathrm{~N}$ & $\%$ & N & $\%$ & $\mathrm{~N}$ & $\%$ \\
\hline E.coli & 99 & 35.2 & 97 & 34.5 & 159 & 56.6 & 0 & .0 & 63 & 22.4 & 182 & 64.8 & 104 & 37 & 54 & 19.2 & 54 & 19.2 & 54 & 19.2 & 69 & 24.6 \\
\hline K. pneumoniae & 17 & 21.0 & 13 & 16.0 & 16 & 19.8 & 0 & .0 & 9 & 11.1 & 29 & 35.8 & 11 & 13.6 & 9 & 11.1 & 9 & 11.1 & 9 & 11.1 & 12 & 14.8 \\
\hline Citrobacter spp. & 31 & 66.0 & 20 & 42.6 & 30 & 63.8 & 0 & .0 & 10 & 21.3 & 22 & 46.8 & 17 & 36.2 & 17 & 15.6 & 17 & 15.6 & 17 & 15.6 & 19 & 40.4 \\
\hline Enterobacter spp. & 1 & 9.1 & 1 & 9.1 & 1 & 9.1 & 0 & .0 & 1 & 9.1 & 2 & 18.2 & 1 & 9.1 & 0 & 0 & 0 & 0 & 0 & 0 & 0 & 0.0 \\
\hline Proteus spp. & 11 & 55.0 & 11 & 55.0 & 11 & 55.0 & 0 & .0 & 1 & 5.0 & 18 & 90.0 & 10 & 50 & 10 & 9.2 & 10 & 9.2 & 10 & 9.2 & 10 & 50 \\
\hline Total & 159 & 36.1 & 142 & 32.3 & 217 & 49.3 & 0 & .0 & 84 & 19.1 & 253 & 57.5 & 143 & 32.5 & 90 & 20.5 & 90 & 20.5 & 90 & 20.5 & 110 & 25 \\
\hline
\end{tabular}

AMC Amoxicillin Clavulanic acid, CTZ Ceftazidime, CRO Ceftriaxone, IMP Imipenem, AK Amikacin, SXT Sulphamethoxazole-Trimethoprim, NA Nalidixic acid, CIP Ciprofloxacin, NOR Norfloxacin, OFX Ofloxacin, F Nitrofurantoin 
Table 4 distribution of PMQR and QRDRs among different FQs resistance phenotypes of Enterobacteriaceae isolated from UTIs

\begin{tabular}{|c|c|c|c|c|c|c|c|}
\hline Species & Phenotype & Resistant to Quinolones & PMQR genes & $\begin{array}{l}\text { MIC of CIP } \\
(\mu \mathrm{g} / \mathrm{mL})\end{array}$ & Number & gyrA alterations & ParC alterations \\
\hline \multirow[t]{6}{*}{ E.coli } & \multirow[t]{2}{*}{ FQ Susceptible } & \multirow[t]{2}{*}{ NA only } & \multirow[t]{2}{*}{ No genes detected } & 0.5 & 31 & Ser83Leu & No mutation \\
\hline & & & & 0.25 & 19 & Ile155Phe & Ser80lle \\
\hline & \multirow[t]{2}{*}{ Intermediate resistance } & \multirow[t]{2}{*}{ NA, CIP, NOR, OFX } & \multirow[t]{2}{*}{ anrB } & 1.5 & 7 & $\begin{array}{l}\text { His80Met } \\
\text { Gly81Ala } \\
\text { Ser83Leu }\end{array}$ & $\begin{array}{l}\text { Met118Trp } \\
\text { Arg119Val }\end{array}$ \\
\hline & & & & 2 & 13 & Ser83Leu & No mutation \\
\hline & High resistance & NA, CIP, NOR, OFX & anrB, anrs & 128 & 28 & $\begin{array}{l}\text { Ser83Tyr } \\
\text { Lys154Arg } \\
\text { Ser171Ala } \\
\text { lle174Thr } \\
\text { Ala175Val }\end{array}$ & Ser80lle \\
\hline & High resistance & NA, CIP, NOR, OFX & qnrB, anrs, qepA & $128,256,512$ & 6 & Asp87Asn & Ser80lle \\
\hline \multirow[t]{4}{*}{ K. pneumoniae } & FQ Susceptible & NA only & No genes detected & 0.5 & 2 & $\begin{array}{l}\text { Lys154Arg } \\
\text { Ala171Ser }\end{array}$ & No mutation \\
\hline & Intermediate resistance & NA, CIP, NOR, OFX & gnrB & 2 & 2 & No mutation & Ser80lle \\
\hline & \multirow[t]{2}{*}{ High resistance } & \multirow[t]{2}{*}{ NA, CIP, NOR, OFX } & \multirow[t]{2}{*}{$q n r B$, anrs } & 128 & 3 & Ser83Tyr & $\begin{array}{l}\text { Ser80lle } \\
\text { Met118lle }\end{array}$ \\
\hline & & & & 512 & 4 & $\begin{array}{l}\text { Ser83Tyr } \\
\text { Ala175Arg } \\
\text { Val176Leu }\end{array}$ & $\begin{array}{l}\text { Ser80lle } \\
\text { Met118lle }\end{array}$ \\
\hline \multirow[t]{3}{*}{ Citrobacter spp. } & Intermediate resistance & NA, CIP, NOR, OFX & anrB & 1.5 & 1 & ND & ND \\
\hline & High resistance & NA, CIP, NOR, OFX & qnrB, anrs & 256 & 15 & \multirow{2}{*}{$\begin{array}{l}\text { Ser83lle } \\
\text { Lys154Arg } \\
\text { Ser171Ala }\end{array}$} & \multirow[t]{2}{*}{ Ser80lle } \\
\hline & High resistance & NA, CIP, NOR, OFX & qnrB, anrs, qepA & 512 & 1 & & \\
\hline Enterobacter spp. & FQ susceptible & NA only & No genes detected & 0.125 & 1 & ND & ND \\
\hline \multirow[t]{2}{*}{ Proteus spp. } & High resistance & NA, CIP, NOR, OFX & anrB, anrs & $125-512$ & 8 & ND & ND \\
\hline & High resistance & NA, CIP, NOR, OFX & $q n r B, q n r S$, qepA & & 2 & ND & ND \\
\hline
\end{tabular}

PMQR Plasmid-mediated quinolone resistance, QRDR Quinolone resistance determining regions, CIP Ciprofloxacin, ND Not determined

outpatients were (73.1\%) and (55.1\%) respectively. A higher frequency of isolation (86\%) was recorded previously in Asia-Pacific region [22]. The frequency of isolation from outpatients agrees with a previous report in Ethiopia $(57.75 \%)$ [23], and disagrees with another report in Korea (89\%) [4]. E. coli was the most frequent followed by $K$. pneumoniae, Citrobacter spp., Proteus spp. and lastly Enterobacter spp. These findings agree with several previous studies [24, 25]. In spite of similarity with these reports, Citrobacter spp. isolation rate in the current study remains the highest. The highest antimicrobial resistance rates were recorded in the present study against SXT with a percentage of (57.5\%) followed by CRO (49.3\%), however, none of the isolates were resistant to imipenem. These findings agree with several previous studies $[4,5]$. High resistance to CRO may be caused by extensive use in the locality. NA has been used for treatment of UTIs for more than five decades [26] so the resistance to NA is expected to be higher than to FQs. In the current study, NA has a resistance rate of (143/440, 32.5\%), however higher rates were reported previously in several studies [23, 25, 27]. The fact that NA is not an empiric treatment of UTI in Egypt may be the cause of this difference. FQs have an overall resistance rate of $(90 / 440,20.5 \%)$. Near results were reported in

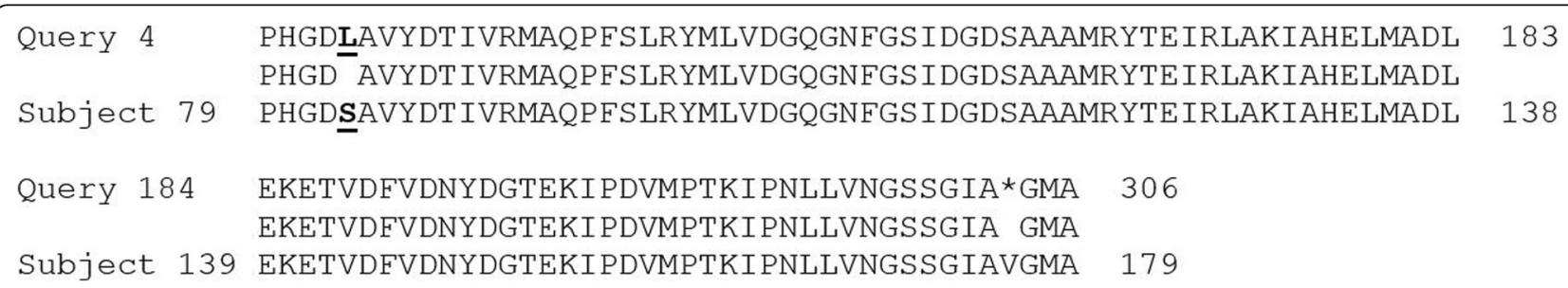

Fig. 1 Alteration in gyr A (codon 83). Nucleotide sequence of a gyrA region of the E. coli FQs-susceptible, WP_074153749.1 DNA gyrase subunit A (E. coli). Alteration in (codon 83) 


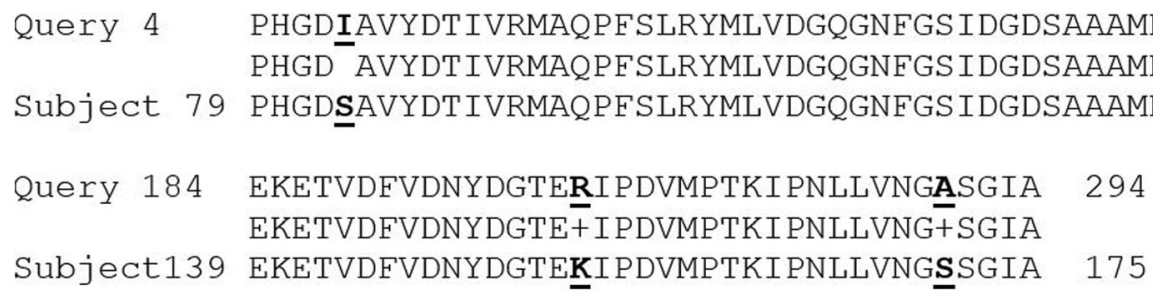

Query 184 EKETVDFVDNYDGTERIPDVMPTKIPNLLVNGA-SGIA 294

EKETVDFVDNYDGTE+IPDVMPTKIPNLLVNG+SGIA

Subject139 EKETVDFVDNYDGTEKIPDVMPTKIPNLLVNG $\underline{S}$ SGIA 175

Fig. 2 Alteration in gyr A (codon 83, 154, 171). Nucleotide sequence of a gyrA region of the Citrobacter spp. high resistance isolates, WP_044266198.1 DNA gyrase subunit A (Citrobacter). Alteration in (codon 83, 154, 171)

Korea (24.8\%) [4], while a higher resistance rate (54.9\%) was recorded in Asian countries [28]. With the analysis of PMQR genes (qnr genes and qepA gene), the most frequent gene was $q n r B$, which was detected in $(62.9 \%)$ of $\mathrm{Q}$ and FQs resistant isolates, and in (100\%) of FQs resistant isolates while qnrS gene was detected in (46.9\%) of Q and FQs resistant isolates and in $(74.4 \%)$ of $\mathrm{FQs} \mathrm{resistant} \mathrm{isolates.} \mathrm{In}$ other studies on Egyptian population, qnrB was the most prevalent $q n r$ gene among $K$. pneumoniae isolates as denoted by El-Badawy et al., 2017 which agree with our results [29], while others reported that qnrS was the most prevalent gene among gram negative bacilli isolated from different clinical settings [10, 11]. QnrB and qnrS genes detection rate in our study was higher than that reported in several previous studies $[27,30]$. Neither $q n r A$ nor $q n r C$ were detected at all, but qepA gene was detected in (10\%) of FQs resistant isolates. In the same context with us, several studies also could not detect qnrA gene among Enterobacteriaceae isolates [27, 30, 31]. However, Szabó et al., 2018 could detect qnrA in their isolates but could not detect neither qurC nor qepA genes [32]. The difference between our results and others may be caused by geographical distribution of qnr genes, type of clinical isolates or the used methods of detection. With considering the analysis of the QRDRs of $\operatorname{gyr} A$ and $\operatorname{parC}$ genes, this study reported that the mutation at position 83 of $g y r A$ was the most frequent in $\mathrm{Q}$ and FQs resistant strains. Three types of amino acid changes resulted from this mutation. Change from serine to leucine in $E$. coli strains which was also reported by many reports [33, 34] and change from serine to tyrosine which was detected in K. pneumoniae and E. coli and was also reported previously [35]. The third change (from serine to isoleucine) was detected in Citrobacter strains and was reported in several studies $[36,37]$. A double concomitant mutation in gyrA A (Lys154Arg and Ser171Ala) was observed in high FQs resistant Citrobacter spp. isolates with MIC of CIP $\geq 256 \mu \mathrm{g} / \mathrm{mL}$ and $E$. coli isolates with MIC of CIP $\geq 128 \mu \mathrm{g} / \mathrm{mL}$. These mutations were reported previously in few studies [35, 38]. Asp-87 Asn mutation of gyrA gene was the least frequent mutation, where it was detected only in high resistant $E$. coli isolates with MIC $\geq 128 \mu \mathrm{g} / \mathrm{mL}$. Therefor the mutation at position 87 of gyrA seemed to contribute to high resistance to FQs, while the mutation at position 83 could contribute to both $\mathrm{Q}$ and FQs resistance. This suggestion agrees with other results [34, 39]. Ser80Ile mutation of parC gene was frequent in both $\mathrm{Q}$ and $\mathrm{FQs}$ resistant strains that agrees with other studies $[40,41]$. Single mutation in either gene occurred only in isolates with MIC of CIP $\leq 2 \mu \mathrm{g} / \mathrm{mL}$, so the presence of double mutation in $g y r A$ and parC genes seemed to be associated with high levels of resistance to FQs. These findings agree with other reports suggested that high levels of FQs resistance appeared to happen as a result of gradual accumulation of QRDR mutations [38, 42]. All isolates with high and intermediate resistance phenotypes harbored one or more PMQR gene, interestingly, isolates with FQs susceptible phenotype (resistant to NA only) harbored none of the tested PMQR genes. This agrees with Rodr'guez-Mart'nez et al., 2016, who stated that resistance to NA only is not enough to suggest presence of PMQR genes [43], while Szabó and his colleagues could found PMQR genes among susceptible or low-level resistance to ciprofloxacin with $(\mathrm{MIC}=0.06-1 \mathrm{mg} / \mathrm{L})$ isolates [32]. Our study also agrees with Piekarska et al., 2015, who stated that combination of

$$
\begin{aligned}
& \text { Query } 4 \text { NTIVRMAQPFSLRYMLVDGQGNFGSIDGDSAAAMRYTEIRLAKIAHELMADLEKETVDFV } \\
& \text { Sbjet } 87 \text { DTIVRMAQPFSLRYMLVDGQGNFGSIDGDSAAAMRYTEIRLAKIAHELMADLEKETVDFV }
\end{aligned}
$$$$
\text { †TIVRMAQPFSLRYMLVDGQGNFGS IDGDSAAAMRYTEIRLAKIAHELMADLEKETVDFV }
$$

Fig. 3 Alteration in gyr A (codon 87). Nucleotide sequence of a gyrA region of the E. coli high resistance isolates, WP_074153749.1 DNA gyrase subunit A (E. coli) Alteration in (codon 87) 


\begin{tabular}{|ll}
\hline Query 14 & PVQRRIVYAMSELGLNASAKFKKSAR \\
Subject 40 & PVQRRIVYAMSELGLNASAKFKKSARYVAMSELGLNASAKFKKSAR \\
& \\
Query 194 & $\begin{array}{l}\text { VDGQGNWGAPDDPKSEAAM } 250 \\
\text { VDGQGNWGAPDDPKSFAAM }\end{array}$ \\
Subject 100 & VDGQGNWGAPDDPKSFAAM 118
\end{tabular}

Fig. 4 Alteration in par C (codon 83). Nucleotide sequence of a parC region of the E. coli high resistance isolates, Reference Sequence Strain. AML00471.1 DNA topoisomerase IV. Alteration in (codon 80)

both PMQR genes and mutations in QRDRs of gyrA and $\operatorname{parC}$ contributes to high resistance to FQs [9].

\section{Conclusion}

In the current study Enterobactericeae remain the most common cause of UTIs. The resistance rate of $\mathrm{Q}$ is (32.5\%), while the resistance to Q and FQs is (20.5\%) among Enterobactericeae isolates. At least one of PMQR gene was detected in FQs resistant isolates. The most frequent gene was qnrB, which was detected in $(62.9 \%)$ of Q resistant isolates followed by qnrS gene which was detected with a percentage of (46.9\%). The co-existence of 2 PMQR genes in the same isolate was observed in (46.9\%) of resistant isolates, while co-existence of 3 PMQR genes was reported in (6.3\%). The presence of at least two PMQR genes together with simultaneous QRDR mutations in each of $g y r A$ and $\operatorname{parC}$ genes can describe the mechanism of resistance in high resistance phenotype (highly resistant to all tested $\mathrm{Q}$ and $\mathrm{FQs}$ ), while presence of at least one PMQR gene together with one QRDR mutation at either genes could be the cause of resistance in isolates with intermediate resistance phenotype (intermediate resistance to all tested Q and FQs). Presence of mutation in only one QRDR regions of gyrA or parC genes could be the cause of resistance to NA only. To our knowledge, the current study is the largest study that reported molecular epidemiology of quinolones resistance in different Enterobacteriaceae species in the study area and could suggest a phenotypic algorithm to describe genetic mechanisms of quinolone resistance.

\section{Supplementary information}

Supplementary information accompanies this paper at https://doi.org/10. 1186/s12879-019-4606-y.

Additional file 1: Figure S1. Agarose gel electrophoresis (1\%) for separation of multiplex PCR products; M is molecular size marker (100 bp ladder), lanes: 1, 2, 3 are positive for qnrB and qnrS, 4, 5 are positive for qnrB. The size of PCR products (in base pairs) is indicated on the right.

Additional file 2: Figure S2. Agarose gel electrophoresis (1\%) for separation of PCR products of qepA; $\mathrm{M}$ is molecular size marker (100 bp ladder), lanes: 1, 2, 3, 4, 5, 6, 9 are positive for qepA, 7, 8 are negative for qepA gene. The size of $P C R$ product (in base pairs) is indicated on the right.

\section{Abbreviations}

CA-UTI: Community-acquired urinary tract infection; CIP: Ciprofloxacin; CRO: Ceftriaxone; FQs: Fluoroquinolones; HAUTI: Healthcare-associated urinary tract infection; MIC: Minimum inhibitory concentration;

PMQR: Plasmid-mediated quinolone resistance; QRDRs: Quinolone resistancedetermining regions; Q: Qunolone; UTI: Urinary tract infection

\section{Acknowledgements}

We thank the health care workers in Minia university hospitals for their cooperation

\section{Authors' contributions}

WKMD, MSM and RMK participated in the study design, DNK carried out most of the data collection, DNK and RMK participated in laboratory work, data analysis and interpretation and drafting the manuscript. All authors have read and approved publication of the final manuscript.

\section{Funding}

None.

\section{Availability of data and materials}

All data generated or analyzed during this study are included in this article [and its supplementary information files (Additional file 1: Figure S1 and Additional file 2: Figure S2)].

\section{Ethics approval and consent to participate}

The study was approved by the Medical Ethics Committee of Minia university Hospital, Egypt. As the study used anonymous clinical data, the patients were not required to give informed consent for the study (code: 45 A at 2/5/2016).

\section{Consent for publication}

Not applicable.

\section{Competing interests}

The authors declare that they have no competing interests.

Received: 1 June 2019 Accepted: 30 October 2019 Published online: 21 November 2019

\section{References}

1. Gupta K, Grigoryan L, Trautner B. Urinary tract infection. Ann Intern Med. 2017;167:ITC49-64.

2. Tandogdu Z, Wagenlehner FM. Global epidemiology of urinary tract infections. Curr Opin Infect Dis. 2016;29(1):73-9.

3. Centers for Disease Control and Prevention (CDC). Urinary Tract Infection (Catheter-Associated Urinary Tract Infection [CAUTI] and Non-CatheterAssociated Urinary Tract Infection [UTI]) and Other Urinary System Infection [USI] Events, National Healthcare Safety Network (NHSN) Patient Safety Component Manual, vol. 7; 2018.

4. Park JJ, Seo YB, Lee J. Antimicrobial Susceptibilities of Enterobacteriaceae in Community-Acquired Urinary Tract Infections during a 5-year Period: A Single Hospital Study in Korea. Infect Chemother. 2017;49(3):184-93.

5. Ponce-de-Leon A, Rodríguez-Noriega E, Morfín-Otero R, et al. Antimicrobial susceptibility of gram-negative bacilli isolated from intra-abdominal and urinary-tract infections in Mexico from 2009 to 2015: Results from the Study 
for Monitoring Antimicrobial Resistance Trends (SMART). PLoS One. 2018; 13(6):e0198621.

6. Strahilevitz J, Jacoby GA, Hooper DC, et al. Plasmid-mediated quinolone resistance: a multifaceted threat. Clin Microbiol Rev. 2009;22(4):664-89.

7. Hooper DC, Jacoby GA. Mechanisms of drug resistance: quinolone resistance. Ann N Y Acad Sci. 2015;1354:12-31.

8. Jacoby GA, Strahilevitz J, Hooper DC. Plasmid-mediated quinolone resistance. Microbiol Spectr. 2014;2(5). https://doi.org/10.1128/microbiolspec. PLAS-0006-2013.

9. Piekarska K, Wołkowicz T, Zacharczuk K, et al. Co-existence of plasmidmediated quinolone resistance determinants and mutations in gyrA and parc among fluoroquinolone-resistant clinical Enterobacteriaceae isolated in a tertiary hospital in Warsaw, Poland. Int J Antimicrob Agents. 2015;45(3):238-43.

10. Hamed SM, Aboshanab KMA, El-Mahallawy HA, Helmy MM, Ashour MS, Elkhatib WF. Plasmid-mediated quinolone resistance in gram-negative pathogens isolated from Cancer patients in Egypt. Microb Drug Resist. 2018; 24(9):1316-25.

11. Khalifa HO, Soliman AM, Ahmed AM, Shimamoto T, Nariya H, Matsumoto T, Shimamoto T. High prevalence of antimicrobial resistance in gram-negative Bacteria isolated from clinical settings in Egypt: recalling for judicious use of conventional antimicrobials in developing nations. Microb Drug Resist. 2019; 25(3):371-85.

12. Tille, Patricia M. Bailey \& Scott's Diagnostic Microbiology; 13th edition. St. Louis: Elsevier. 2014;3(73):919-929.

13. Clinical and Laboratory Standards Institute (CLSI). Performance Standards for Antimicrobial Susceptibility Testing. In: CLSI supplement M100S. 26th ed. Wayne: Clinical and Laboratory Standards Institute; 2016.

14. Clinical and Laboratory Standards Institute (CLSI). Performance standards for Antimicrobial Disk Susceptibility Tests; Approved Standard. In: CLSI document M02-A12. 12th ed. Wayne: Clinical and Laboratory Standards Institute; 2015

15. CLSI*. Methods for Dilution Antimicrobial Susceptibility Tests for Bacteria that grow aerobically; Approved Standard. In: CLSI document M07-A10. 10th ed. Wayne: Clinical and Laboratory Standards Institute; 2015.

16. Cattoir V, Poirel L, Rotimi V, et al. Multiplex PCR for detection of plasmidmediated quinolone resistance qnr genes in ESBL-producing enterobacterial isolates. J Antimicrob Chemother. 2007;60(2):394-7.

17. Wang M, Guo Q, Xu X, et al. New plasmid-mediated quinolone resistance gene, anrC, found in a clinical isolate of Proteus mirabilis. Antimicrob Agents Chemother. 2009:53(5):1892-7.

18. Cruz GR, Radice M, Sennati S, et al. Prevalence of plasmid-mediated quinolone resistance determinants among oxyiminocephalosporin-resistant Enterobacteriaceae in Argentina. Mem Inst Oswaldo Cruz. 2013;108(7):924-7.

19. Cano ME, Rodríguez-Martínez JM, Agüero J, et al. Detection of plasmidmediated quinolone resistance genes in clinical isolates of Enterobacter spp. in Spain. J Clin Microbiol. 2009;47(7):2033-9.

20. Vila J, Ruiz J, Goñi P, et al. Mutation in the gyrA gene of quinolone-resistant clinical isolates of Acinetobacter baumannii. Antimicrob Agents Chemother. 1995;39(5):1201-3

21. Foxman B. Urinary tract infection syndromes: occurrence, recurrence, bacteriology, risk factors, and disease burden. Infect Dis Clin N Am. 2014; 28(1):1-13.

22. Lu PL, Liu YC, Toh HS, et al. Epidemiology and antimicrobial susceptibility profiles of gram-negative bacteria causing urinary tract infections in the Asia-Pacific region: 2009-2010 results from the study for monitoring antimicrobial resistance trends (SMART). Int J Antimicrob Agents. 2012:40:37-43.

23. Derese B, Kedir H, Teklemariam Z, et al. Bacterial profile of urinary tract infection and antimicrobial susceptibility pattern among pregnant women attending at Antenatal Clinic in Dil Chora Referral Hospital, Dire Dawa, Eastern Ethiopia. Ther Clin Risk Manag. 2016;18:12251-60.

24. Abujnah AA, Zorgani A, Sabri MA, et al. Multidrug resistance and extendedspectrum $\beta$-lactamases genes among Escherichia coli from patients with urinary tract infections in northwestern Libya. Libyan J Med. 2015;2:1026412.

25. Azargun R, Sadeghi MR, Soroush Barhaghi MH, et al. The prevalence of plasmid-mediated quinolone resistance and ESBL-production in Enterobacteriaceae isolated from urinary tract infections. Infect Drug Resist. 2018:23(11):1007-14.

26. Emmerson AM, Jones AM. The quinolones decades of development and use. J Antimicrob Chemother. 2003:51(Suppl 1):13-20.
27. Sedighi I, Arabestani MR, Rahimbakhsh A, et al. Dissemination of extendedSpectrum $\beta$-lactamases and quinolone resistance genes among clinical isolates of Uropathogenic Escherichia coli in children. Jundishapur J Microbiol. 2015;8(7):e19184.

28. Choe HS, Lee SJ, Cho YH, et al. GPIU Asian Investigators. Aspects of urinary tract infections and antimicrobial resistance in hospitalized urology patients in Asia: 10-year results of the global prevalence study of infections in urology (GPIU). J Infect Chemother. 2018;24(4):278-83.

29. El-Badawy MF, Tawakol WM, El-Far SW, Maghrabi IA, Al-Ghamdi SA, Mansy MS, Ashour MS, Shohayeb MM. Molecular identification of aminoglycosidemodifying enzymes and plasmid-mediated quinolone resistance genes among Klebsiella pneumoniae clinical isolates recovered from Egyptian patients. Int J Microbiol. 2017;2017:8050432.

30. Zhao L, Zhang J, Zheng B, et al. Molecular epidemiology and genetic diversity of fluoroquinolone-resistant Escherichia coli isolates from patients with community-onset infections in 30 Chinese county hospitals. J Clin Microbiol. 2015;53(3):766-70.

31. Benaicha H, Barrijal S, Ezzakkioui F, et al. Prevalence of PMQR genes in E. coli and Klebsiella spp. isolated from North-West of Morocco. J Glob Antimicrob Resist. 2017;10:321-5.

32. Szabó O, Gulyás D, Szabó N, et al. Plasmid-mediated quinolone resistance determinants in Enterobacteriaceae from urine clinical samples. Acta Microbiol Immunol Hung. 2018;65:231-11.

33. Kariuki S, Revathi G, Corkill J, et al. Escherichia coli from community-acquired urinary tract infections resistant to fluoroquinolones and extended-spectrum beta-lactams. J Infect Dev Ctries. 2007:1(3):257-62.

34. Varughese LR, Rajpoot M, Goyal $\mathrm{S}$, et al. Analytical profiling of mutations in quinolone resistance determining region of gyrA gene among UPEC. PLOS One. 2018;13(1):e0190729.

35. Araújo BF, Campos PA, Royer $\mathrm{S}$, et al. High frequency of the combined presence of QRDR mutations and PMQR determinants in multidrug-resistant Klebsiella pneumoniae and Escherichia coli isolates from nosocomial and community-acquired infections. J Med Microbiol. 2017;4:1144-50.

36. Ogbolu DO, Daini OA, Ogunledun A, et al. Effects of gyrA and parC mutations in quinolones resistant clinical gram negative Bacteria from Nigeria. Afr J Biomed Res. 2012;15:97-104

37. Asadpour L. Study of amino acid alteration in graA \& parC genes in quinolone resistant Klebsiella pnemoniae. Crescent J Med Biol Sci. 2017;4:3-6.

38. Norouzi A, Azizi $\mathrm{O}$, Hosseini $\mathrm{H}$, et al. Amino acid substitution mutations analysis of gyrA and parC genes in clonal lineage of Klebsiella pneumoniae conferring high-level quinolone resistance. JoMMID. 2014;2(3):109-17.

39. Vila J, Ruiz J, Marco F, et al. Association between double mutation in gyrA gene of ciprofloxacin-resistant clinical isolates of Escherichia coli and MICS. Antimicrob Agents Chemother. 1994;38(10):2477-9.

40. Lorestani RC, Akya A, Elahi A. The Mutations of Topoisomerase Genes and Their Effect on Resistance to Fluoroquinolones in Extended-Spectrum -Lactamase-Producing Escherichia coli. Jundishapur J Nat Pharm Prod. 2018; 13(1):e57964.

41. Mirzaii M, Jamshidi S, Zamanzadeh $M$, et al. Determination of gyrA and parC mutations and prevalence of plasmid-mediated quinolone resistance genes in Escherichia coli and Klebsiella pneumoniae isolated from patients with urinary tract infection in Iran. J Glob Antimicrob Resist. 2018;13:197-200.

42. Heisig P. Genetic Evidence for a Role of parC Mutations in Development of High-Level Fluoroquinolone Resistance in Escherichia coli. Antimicrob Agents Chemother. 1996;40:879-85.

43. Rodríguez-Martínez JM, López-Cerero L, Díaz-de-Alba P, et al. Assessment of a phenotypic algorithm to detect plasmid-mediated quinolone resistance in Enterobacteriaceae. J Antimicrob Chemother. 2016;71(3):845-7.

\section{Publisher's Note}

Springer Nature remains neutral with regard to jurisdictional claims in published maps and institutional affiliations. 